\title{
The Effects of COVID-19 Lockdown on Air Quality in Macedonia
}

\author{
Mirjana Dimovska ${ }^{1,2 *}$, Dragan Gjorgjev ${ }^{1,2}$ \\ ${ }^{1}$ Institute of Public Health of Republic of Macedonia, Skopje, Republic of Macedonia; ${ }^{2}$ Faculty of Medicine, Ss. Cyril and \\ Methodius University of Skopje, Skopje, Republic of Macedonia
}

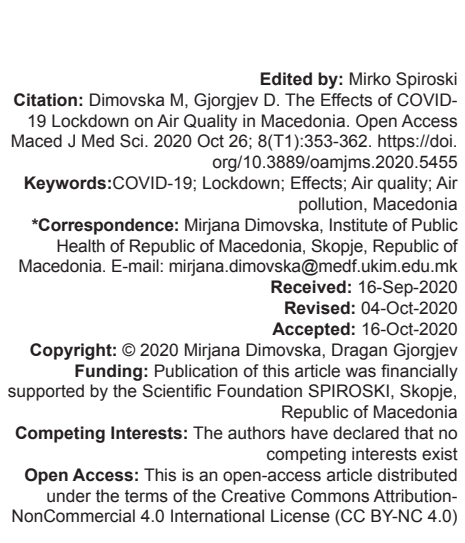

\section{Introduction}

Starting from December 31, 2019, when the first cluster of cases of pneumonia in Wuhan, Hubei Province (China) has been reported, a novel coronavirus was eventually identified. Setting the Incident Management Support Team, reporting on social media and publishing the first disease outbreak news, World Health Organization (WHO) took a comprehensive package of measures providing to all countries a guide how to detect, test, and manage potential cases with knowledge regarding the virus present at that time. One month later, after the first reports of limited human-to-human transmission were reported outside China, WHO Director-General accepted recommendation of emergency committee and declared a novel coronavirus outbreak (2019-nCoV) as a Public Health Emergency of International Concern (PHEIC). This is the $6^{\text {th }}$ time, the WHO has declared a PHEIC since the International Health Regulations (IHR) came into force in 2005 [1]. The response worldwide varied from restrictions of the human public gatherings and interaction to various types of restricted economic activities. As of May 7, 3,672,238 confirmed cases have been reported in 215 countries and territories worldwide, with 254,045 confirmed death cases [1], [2].

Republic of Macedonia has confirmed its first case of SARS-CoV-2 on February 26, 2020, with a positive epidemiological anamnesis that has been traveling in Northern Italy. Initial national measures against a potential outbreak and treat have been implemented in late of January starting with installing thermal camera at the national airport and providing personal protective equipment and reagents for virus detection. Series of public health measures and recommendations followed.

Increasing number of new cases, led to a need for implementation of more reliable measures to prevent further spreading of the virus. On March 10, closure of all education institutions (from kindergartens to universities) has been introduced. A state of emergency was declared on March 18 and first movement restrictions were introduced on March 23 on the national level. However, restriction of the movement from 9 pm to 5 am next day in working days and special regime for elderly and younger than 18, has not been sufficient to control spreading of the virus. Thus, stricter movement restrictions were introduced on April 8 
(ban for movement from $4 \mathrm{pm}$ to 5 am next day and complete ban during the weekends, starting from $4 \mathrm{pm}$ on Friday to 5 am on Monday). Complete lockdown was introduced during religious holidays in the country, Orthodox Easter (17-21 April) and during Eid al-Fitr (24-26 May) to prevent further spreading of the virus caused by traditional family reunions, as well for the International Labor Day (from 1 May to 4 May) [3].

On May 7, 1572 confirmed cases have been reported in Macedonia, and 89 death cases.

The scale, suddenness, and global scope of the pandemic have raised urgent and coordinated actions to identify the key factors including ambient air pollution as a modifiable environmental factor that could increase the severity of the health outcomes and other social and economic consequences of the pandemic [4]. In reality, the world was facing a tremendous decline in air pollutant concentration especially in nitrogen dioxide $\left(\mathrm{NO}_{2}\right)$. National Aeronautics and Space Administration (NASA) [5] and European Space Agency ${ }^{1}$ satellite [6] images visualized that significant reduction in $\mathrm{NO}_{2}$ in China from January to February. According to the evidence, this change is at least partly related to the economic slowdown following the outbreak of coronavirus, namely, shutting down the transportation into and out of Wuhan, local business as well to reduce spread of the disease have resulted with decrement of nitrogen dioxide.

NASA scientist has previously seen such a decline during other events: economic recession in 2008, Beijing Olympic games in 2008, but those were gradual, or around the city, different than this dramatic drop-of on a wide area due to pandemic [5].

And while the pandemic continues to reap human lives, many countries have reported an improvement in the quality of environmental media and a return of biodiversity even in urban areas. Due to restricted movement and gathering of the people, non-functioning industries, almost empty streets and roads, ecosystems started to recover [7], [8], [9]. That was an ideal moment to analyze the effect of this unexpected situation on the air quality in some cities and to look for any possible decline of the pollutant concentration related to the decreased or stopped economic activities due to pandemic.

This study aims to assess the impact of COVID-19 lockdown ${ }^{2}$ conditions (especially reduction of the traffic among other sources of pollution) on the air quality of the four selected cities in Republic of Macedonia.

\footnotetext{
$1 \quad$ NASA collect the data using Ozone Monitoring Instruments (OMI) on its AURA satellite. While, ESA collect the data through Sentinel-5P satellite using TROPOMI (TROPOsphericMonitoring Instrument).

$2 \quad$ Lockdown in general means that people need to stay indoors but can go out to buy essential commodities. In the Macedonia case means all commercial establishments to be shut down, except for those providing essential services. Places of mass gatherings such as malls, theatres, stadiums, etc. have been shut completely, curfew has been introduced and special permits for movement have been issued.
}

\section{Materials and Methods}

To compare current air quality and air pollutant levels to years past, we have analyzed the daily mean concentration of the particulate matter $\left(\mathrm{PM}_{10}\right.$ and $\left.\mathrm{PM}_{2.5}\right)$, nitrogen dioxide $\left(\mathrm{NO}_{2}\right)$, ozone $\left(\mathrm{O}_{3}\right)$, and carbon monoxide (CO), measured in the national air quality monitoring network in the selected cities: The City of Skopje, Bitola, Tetovo, and Kumanovo.

The pollutant concentration was analyzed separately comparing following periods: Last week of February 2020 to the end of May 2020 (named COVID19 period) with the same period in 2017-2019 (nonCOVID-19 period).

\section{Statistical analysis}

Statistical analysis of the data is performed using the IBM Statistical Package for the Social Sciences (IBM SPSS Statistic for Windows, Version 19.0. Amonk, NY: IBM Corp.). The following methods have been applied: Descriptive statistics is done in series with numerical marks (pollutants concentration), means and standard deviation; $\pm 95 \% \mathrm{Cl}$, minimum, and maximum. Correlation matrix between air pollutants has been made and Spearman correlation coefficient calculated.

Assumptions checking are performed to run appropriate test (significant outliers, data distribution - tests of normality (skewness and kurtosis, Shapiro-Wilk and Kolmogorov-Smirnov test, and homogeneity of variances - Levene's test). Depending on the data distribution, parametric independent-samples t-test or nonparametric Mann-Whitney U-test were run to determine if there were differences in the pollutants concentration during the COVID-19 and non-COVID-19 period.

\section{Study area}

Based on the latest State Statistical Office estimates, in 2019, Republic of Macedonia has 2.076,255 inhabitants, the City of Skopje 554,972 residents (26.7\% of the total population), Bitola 90,895 and Tetovo 92,946 and Kumanovo 109,521 that present about $14.1 \%$ of the total population [10]. We analyze the City of Skopje only as a separate unit of the local self-governmentconsisting ten urban municipalities. The broader area (Skopje Region) comprised seven more rural municipalities and it is not covered by this study. In Bitola, one urban and 64 rural settlements are present while municipality of Tetovo, comprises one urban and 19 rural settlements and municipality of Kumanovo with 37 rural settlements [11], [12].

The City of Skopje as a capital city of the Republic of Macedonia is the main educational, political economic and cultural center in the country. The last decade it is one of the most polluted cities in the world. With an average annual concentration of $\mathrm{PM}_{10}$ ranging from 49.6 
to $124.3 \mu \mathrm{g} / \mathrm{m}^{3}$ in the period $2010-2019$ for the City of Skopje; $49.6-147.2 \mu \mathrm{g} / \mathrm{m}^{3}$ in Tetovo; and $44.2-89.6 \mu \mathrm{g} /$ $\mathrm{m}^{3}$ in Bitola, particulate air pollution is top priority public health and environmental problem in entire country. The mountainous terrain and meteorological conditions cause extra challenges for the national air quality management. Many sources of air pollution have been identified: Traffic (poorly maintained vehicle fleet), domestic heating, and energy production which rely mostly on poor-quality lignite in old thermal power plants, the absence of proper waste management, etc. [11].

\section{Environmental data}

Daily mean concentration of selected pollutants $\left(\mathrm{PM}_{10}, \mathrm{PM}_{2.5}, 8\right.$-h ozone, $\mathrm{NO}_{2}$, and $\left.\mathrm{CO}\right)$ from five monitoring stations in the City of Skopje, one located in Tetovo and Kumanovo, and two in Bitola was analyzed. Data have been obtained from the Macedonian Environmental Information Centre (MEIC) in the Ministry of Environment and Physical Planning (MEPP).

\section{Meteorological data}

Due to poor maintenance of the monitoring stations within national air quality monitoring network, very often meteorological data are absent (notmeasured) or there is not continuity in the measurements. Thus, we present only daily mean temperature of the ambient air, wind speed, and relative humidity for Skopje and Bitola, measured in monitoring station Centar for the City of Skopje and average temperature of both monitoring station in Bitola (Tables 1 and A1). There are no continuous measurements of meteorological data from other monitoring stations (Kumanovo and Tetovo).

Table 1: Meteorological conditions for non-COVID-19 and COVID-19 period

\begin{tabular}{|c|c|c|c|c|c|c|}
\hline \multirow[t]{2}{*}{ Meteorological factor } & \multicolumn{3}{|l|}{$2017-2020$} & \multicolumn{3}{|c|}{ COVID-19, 2020} \\
\hline & Avg. \pm Std & Min & $\operatorname{Max}$ & Avg. \pm Std. & Min & Max \\
\hline \multicolumn{7}{|l|}{ Temperature $\left({ }^{\circ} \mathrm{C}\right)$} \\
\hline Skopje & $14.2 \pm 5.4$ & -4.2 & 23.9 & $12.4 \pm 5.4$ & 0.8 & 24.9 \\
\hline Bitola & $10.9 \pm 5.2$ & -6.1 & 21.1 & $10.4 \pm 5.6$ & -0.6 & 24.4 \\
\hline \multicolumn{7}{|l|}{ Wind speed $(\mathrm{m} / \mathrm{s})$} \\
\hline Skopje & $0.6 \pm 0.4$ & 0.0 & 2.5 & $0.6 \pm 0.4$ & 0.0 & 1.5 \\
\hline Bitola & $0.3 \pm 0.2$ & 0.0 & 1.1 & $0.3 \pm 0.2$ & 0.0 & 1.0 \\
\hline \multicolumn{7}{|l|}{ Humidity (\%) } \\
\hline Skopje & $61.1 \pm 12.3$ & 31 & 92 & $61.8 \pm 13.8$ & 37 & 94 \\
\hline Bitola & $63.2 \pm 12.6$ & 36 & 95 & $63.4 \pm 16.2$ & 33 & 97 \\
\hline
\end{tabular}

\section{Results}

Aiming to understand the impact of implementation of the collective measures of restrictions as a response of the COVID-19 outbreak on the air quality, we have analyzed particulate matter (both, $\mathrm{PM}_{10}$ and $\mathrm{PM}_{2.5}$ ), $\mathrm{NO}_{2}$, ozone, and carbon monoxide obtained from the national air quality monitoring network of MEPP in the selected cities. Then, we compared the pollutants concentrations week by week during COVID-19 period with the average levels for the same time period from 2017, 2018, and 2019 (or, in some cases for 2018 and 2019), and \% of change compared with previous week of the COVID-19 period only.

For that purpose, several tables (Appendix, Tables A1-A6) were prepared.

We have found an evident decrease in the concentration levels of all pollutants measured during COVID-19 period in 2020 compared to those from 2017 to 2019 (or 2018-2019), with some exceptions for $\mathrm{PM}_{2.5}$ in Kumanovo (7\% higher concentration) and carbon monoxide in Skopje (3\% higher concentration). The most notable and sharp decrement were for $\mathrm{NO}_{2}$, with a concentration $5-31 \%$ lower during COVID-19 period (Table 2).

Table 2: Average concentration of the air pollutants during non-COVID-19 and COVID-19 period

\begin{tabular}{lllllll}
\hline City & Period & $\mathrm{PM}_{10}$ & $\mathrm{PM}_{25}$ & $\mathrm{NO}_{2}$ & Ozone & $\mathrm{CO}$ \\
\hline Skopje & $2017-2019$ & 41.8 & 26.6 & 26.1 & 39.6 & 0.44 \\
& COVID-19, 2020 & 34.1 & 22.3 & 18.1 & 37.4 & 0.46 \\
\multirow{4}{*}{ Bitola } & $\%$ change & -18 & -16 & -31 & -6 & 3 \\
& 2017-2019 & 37.4 & $22.6^{*}$ & 14.6 & 59.6 & 0.36 \\
& COVID-19, 2020 & 35.8 & 22.1 & 11.1 & 49.0 & 0.32 \\
Tetovo & \% change & -4 & -2 & -24 & -18 & -10 \\
& 2017-2019 & 40.8 & $29.2^{*}$ & $24.8^{*}$ & 41.5 & 0.37 \\
& COVID-19, 2020 & 39.0 & 27.0 & 18.2 & 24.9 & 0.36 \\
\multirow{2}{*}{ Kumanovo } & \% change & -5 & -7 & -27 & -40 & -4 \\
& 2017-2019 & 45.7 & $26.2^{*}$ & $20.2^{*}$ & $38.1^{*}$ & 0.50 \\
& COVID-19, 2020 & 41.9 & 28.2 & 19.2 & 20.4 & 0.34 \\
& \% change & -8 & 7.0 & -5 & -47 & -31 \\
\hline *Two years' average, 2018 to 2019; Source: MEIC, MEPP, 2020 & & &
\end{tabular}

On Figures 1-5 are presented the effect of some major implemented measures of restrictions on the air quality during the COVID-19 pandemic.

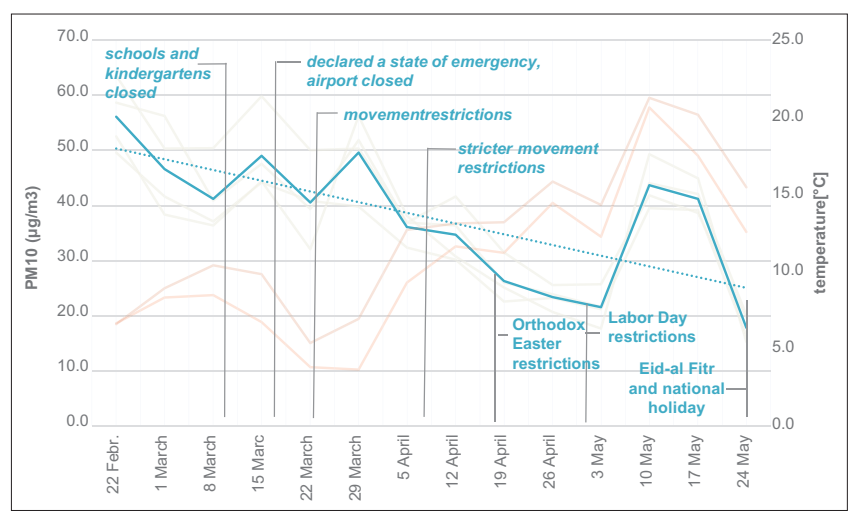

Figure 1: Effects of the implemented measures on the week average concentration of $P M_{10}$. Dark blue line: Average concentration of the four cities; light gray lines: Measured weekly concentration of $P M_{10}$; light red lines: Ambient air temperature, weekly average measured in Skopje and Bitola

Detailed analysis of the data shows that the fourth observed week (15-21 March 2020) had high percentage change of particles concentration compared to the previous week $(16 \%-22 \%$ increment of PM10 concentration and $19 \%$ to $27 \%$ of PM 2.5 concentration); the highest percentage change of particles concentartion was reported in the twelve week (10-16 May) were the increment of PM10 concentration from $63 \%$ to $189 \%$ have been reported and $8 \%$ to $61 \%$ for PM2.5; in the sixth week (29 March to 4 April) was reported high percentage change of PM concentration in Bitola and Tetovo $(76 \%$ and $32 \%$ for PM10 and $67 \%$ and $23 \%$ for PM2.5 respectively) (Tables A2 and A3, Figures 1 and 2). 


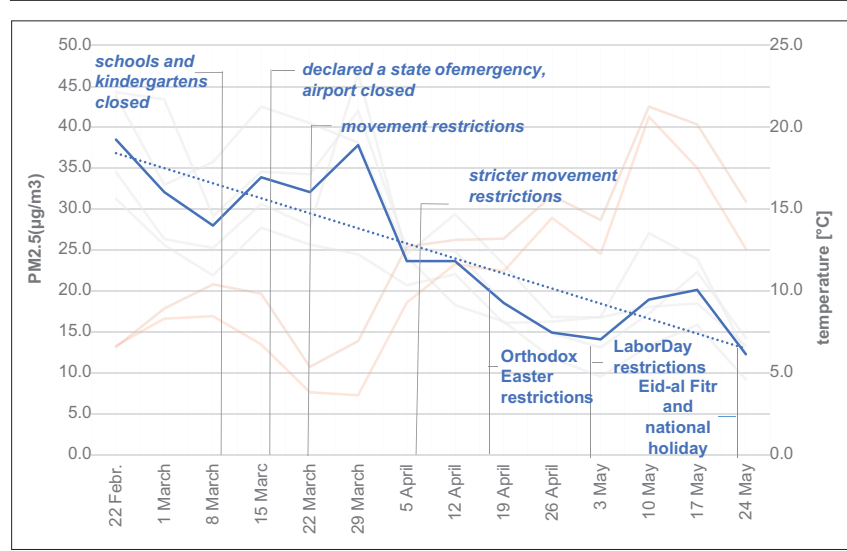

Figure 2: Effects of the implemented measures on the week average concentration of $\mathrm{PM}_{2.5}$. Dark blue line: Average concentration of the four cities; light gray lines: Measured weekly concentrations of $P M_{2.5}$; light red lines: Ambient air temperature, weekly average measured in Skopje and Bitola

In terms of $\mathrm{NO}_{2}$ concentration, such an increment is notable in the 12 observed week and for ozone, in the $4^{\text {th }}, 6^{\text {th }}$, and $7^{\text {th }}$ week of the analyzed period in 2020 (Figure 3, Tables A4 and A5).

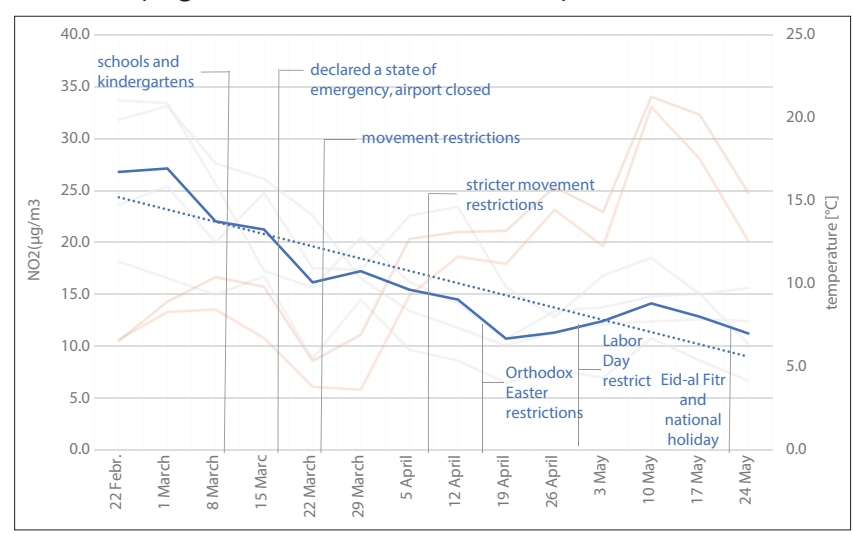

Figure 3: Effects of the implemented measures on the week average concentration of $\mathrm{NO}_{2}$. Dark blue line: Average concentration of the four cities; light gray lines: Measured weekly concentrations of $\mathrm{NO}_{2}$; light red lines: Ambient air temperature, weekly average measured in Skopje and Bitola

Regarding the temperature, there is no obvious change during two periods in Bitola $\left(10.9 \pm 5.2^{\circ} \mathrm{C}\right.$ vs. $10.4 \pm 5.6^{\circ} \mathrm{C}$ in 2020 ), while in Skopje, the temperature

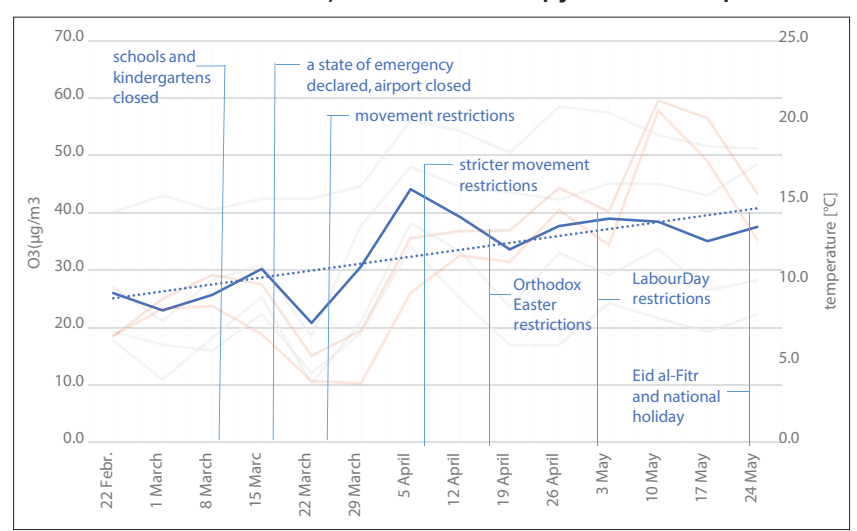

Figure 4: Effects of the implemented measures on the week average concentration of ozone. Dark blue line: Average concentration of the four cities; light gray lines: Measured weekly concentrations of ozone; light red lines: Ambient air temperature, weekly average measured in Skopje and Bitola

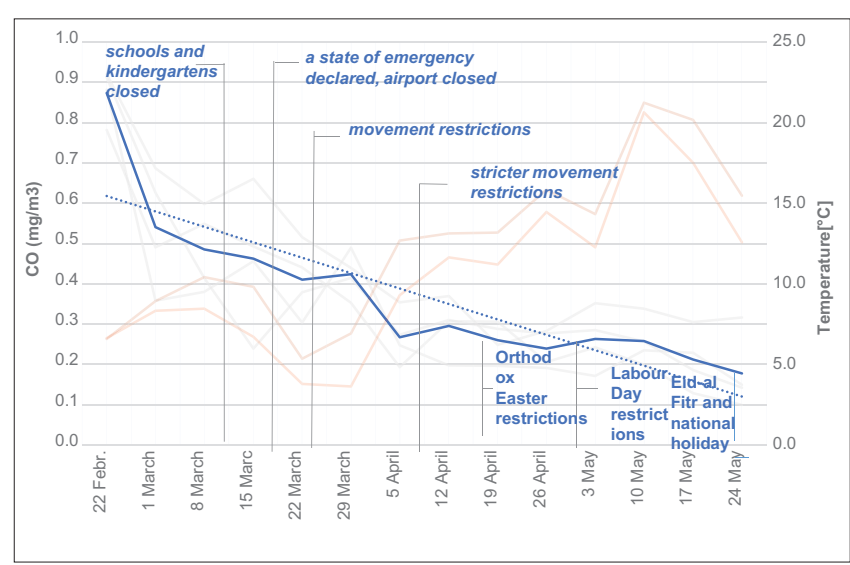

Figure 5: Effects of the implemented measures on the week average concentration of carbon monoxide. Dark blue line: Average concentration of the four cities; light gray lines: Measured weekly concentrations of carbon monoxide; light red lines: Ambient air temperature, weekly average measured in Skopje and Bitola

is lower in $2020\left(12.4 \pm 5.4^{\circ} \mathrm{C}\right)$ compared to $2017-2019$ period $14.2 \pm 5.4^{\circ} \mathrm{C}$ (Table 1). The period from 22 February to the end of May 2020 in the City of Skopje was characterized with minimum daily temperature $\left(0.8^{\circ} \mathrm{C}\right)$ and maximum daily temperature $\left(24.9^{\circ} \mathrm{C}\right)$ that presents $\left(24.2^{\circ} \mathrm{C}\right)$ difference. The difference in Bitola was $24.9^{\circ} \mathrm{C}$ (minimum daily temperature $-0.6-24.4^{\circ} \mathrm{C}$ maximum daily temperature). Both differences are significant, but absence of meteorological data for other two cities prevents a final conclusion to be reached.

In terms of the wind speed and humidity, there are no any significant differences in the two analyzed periods (Table 1).

Due to violation of the assumptions for normality of the data distribution, significant statistical difference has been found between the concentrations of $\mathrm{PM}_{10}$ in COVID-19 period, 2020 compared to the same period in 2017-2019 in Skopje using Mann-Whitney U-test. COVID-19 period were associated with statistically significantly lower concentration of $\mathrm{PM}_{10}, 34.1 \mu \mathrm{g} / \mathrm{m}^{3}$ $(M d n=29.9)$, compared to the 3-years period, $40.6 \mu \mathrm{g} /$ $\mathrm{m}^{3,}(M d n=37.8)$. Mann-Whitney U-test indicated that the difference was statistically significant, $U\left(N_{\text {CoviD-19 }}\right.$ period $\left.=100, N_{\text {non-CoVID-19 period }}=297\right)=10670.00, z=-4.21$, $\mathrm{p}=0.000$

Same apply for the concentration of $\mathrm{PM}_{2.5}$ in Skopje, where the mean concentration of particles during COVID-19 period was $22.0 \mu \mathrm{g} / \mathrm{m}^{3}$, $(M d n=20.9)$, while for the previous 3-years period was higher, $26.1 \mu \mathrm{g} / \mathrm{m}^{3}$, $(M d n=24.7)$. Mann-Whitney U-test indicated that the difference was statistically significant, $U\left(N_{\text {covID-19 period }}=100\right.$, $\left.N_{\text {non-CoVID-19 period }}=297\right)=11810.00, z=-3.06, p=0.002$.

The most notable decrement of the pollutant concentration obviously due to the decreased human activity during COVID-19 pandemic in Republic of Macedonia was found for $\mathrm{NO}_{2}$ concentrations. Data distributions for $\mathrm{NO}_{2}$ in Skopje and Bitola were sufficiently normal for the purposes of conducting a t-test (i.e., skew $<|2.0|$ and kurtosis $<|7.0|$, z-score was calculated [13], 
[14], Shapiro-Wilk test and Kolmogorov-Smirnov test $>0.05$. Homogeneity of variances was tested through Levene's F test.

The City of Skopje, with an average concentration of $\mathrm{NO}_{2}$ of $18.1 \mu \mathrm{g} / \mathrm{m}^{3}$ in 2020 compared to $26.1 \mu \mathrm{g} / \mathrm{m}^{3}$ during $2017-2019$, was the most notable prove of effectiveness of the reduced human activities in the country due to COVID-19 pandemic. An independent samples t-test confirmed the statistically significant difference between two analyzed periods $(\mathrm{M}=18.1$, $\mathrm{SD}=9.04$ for the COVID-19 period) and $M=26.1$ $\mathrm{SD}=8.29$ for 3 -years period; $\mathrm{M}=7.93,95 \% \mathrm{Cl}[6.01$, 9.86], $\mathrm{t}(395)=8.09, \mathrm{p}=0.000$. In Bitola, the difference in the concentrations was smaller but still, statistically significant $M=15.8, S D=6.81$ for the COVID-19 period, and $\mathrm{M}=17.5, \mathrm{SD}=7.60$ for non-COVID 2 years period $\mathrm{M}=1.64,95 \% \mathrm{Cl}[0.08,3.21], \mathrm{t}(383) 2.06, \mathrm{p}=0.040$.

In Tetovo, statistically significant difference in terms of $\mathrm{NO}_{2}$ concentration has been found as well, 18.8 $\mu \mathrm{g} / \mathrm{m}^{3,}(M d n=16.1)$, and $25.1 \mu \mathrm{g} / \mathrm{m}^{3},(M d n=23.4)$ during 2017-2018 (Mann-Whitney test, $U\left(N_{\text {CovID-19 period }}=100\right.$, $\left.\left.N_{\text {non-Covid-19 period }}=192\right)=5147.00, z=-6.50, p=0.000\right)$.

In terms of ozone, statistically significant lower concentrations were found in all cities with exemption of the City of Skopje. The higher drop of the ozone concentrations was found in Kumanovo (-47\%) and Tetovo $(-40 \%)$ (Table 1). Lower average ozone concentration was reported in 2020 in Kumanovo ( $M=20.5$, SD = 7.95), while in non-COVID-19 period $\mathrm{M}=39.0, \mathrm{SD}=12.41 ; \mathrm{M}$ $=18.49,95 \% \mathrm{Cl}[16.11,20.88], t(275) 15.27, p=0.000$; Tetovo $(\mathrm{M}=25.0, \mathrm{SD}=11.39$ for COVID-19 period, and $\mathrm{M}=41.5, \mathrm{SD}=13.21$ for non-COVID-19 period, and $\mathrm{M}=$ $16.45,95 \% \mathrm{Cl}[13.53,19.37], t(381) 11.08, p=0.000$; and Bitola $(\mathrm{M}=49.2, \mathrm{SD}=9.41$ for 2020 and $\mathrm{M}=59.1, \mathrm{SD}=$ 11.91 for non-COVID-19 period, and $\mathrm{M}=9.87,95 \% \mathrm{Cl}$ [7.57, 12.17], $t(214) 8.452, p=0.000$.

Unexpectedly, in our study, we found statistically significant higher concentration of carbon monoxide in Skopje, $0.532 \mathrm{mg} / \mathrm{m}^{3}(M d n=0.39)$ in 2020, and 0.440 $\mathrm{mg} / \mathrm{m}^{3}(M d n=0.37)$ during 3 years period $\left(U\left(N_{\text {COVID-19 }}\right.\right.$ period $\left.=69, N_{\text {non-CoVID-19 period }}=296\right)=8049.00, z=-2.74$, $p=0.006)$. The same situation was confirmed in Tetovo where the concentration of carbon monoxide during the pandemic in 2020 was higher, $0.459 \mathrm{mg} / \mathrm{m}^{3}(\mathrm{Mdn}$ $=0.30)$ and $0.357 \mathrm{mg} / \mathrm{m}^{3}(M d n=0.27)$ in 2017-2019 $\left(U\left(N_{\text {CoVID-19 period }}=69, N_{\text {non-COVID-19 period }}=296\right)=6954.00\right.$, $z=-4.13, p=0.000)$.

\section{Discussion}

\section{Impact of the lockdown on the particulate} matter

The observed period (last week of February to the end of May) is somehow a transitional period in terms of ambient temperature characterized with gradual increment of the temperature and consequently subsequent lesser use of the wood (or coal) for household heating. In the source apportionment study for the City of Skopje (2015-2016), biomass combustion from household heating has been identified as a major source of pollution, contributing with $36 \%$ of the total share of emissions of particulate matter [11]. The trend of the $\mathrm{PM}_{10}$ and $\mathrm{PM}_{2.5}$ concentrations is declining in the same period of preceding 3-years (the end of February to May). However, in 2020 the concentrations are $18 \%$ and $16 \%$ lower, indicating that these changes in air pollution caused by city lockdown are unlikely to be correlated with other factors like weather conditions or to be coincidental (Table 2, Tables A2 and A3).

On March 10, closure of all education institutes (from kindergartens to universities) has been introduced. The slight reduction of the PM concentrations (15-18\% lower concentration of $\mathrm{PM}_{2.5}$ compared to the previous week), probably could not be attributed to this decision due to same trend of decrement in the pre-COVID 3-years period. Instead to have same decreasing trend further on, concentration of PM particles during the $4^{\text {th }}$ week of the analyzed period started to increase in all cities (16-22\% higher than previous week). The unfavorable meteorological conditions small decrement of the ambient temperature (6\% in Skopje and $21 \%$ in Bitola), as well as drop of the wind speed (36\% decline in Bitola), could be a possible explanation (Table A1).

The first movement restrictions in the country were introduced on March 23, followed by stricter movement restrictions on April 8 (Figures 1 and 2). As a result, substantial decrement of $\mathrm{PM}$ concentrations has been reported in all cities observed in the study (19-32\% for $\mathrm{PM}_{10}$, and $15-48 \%$ for $\mathrm{PM}_{2.5}$ in the $7^{\text {th }}$ week during COVID-19 period) (Tables A2 and A3). That was likely attributable to the significant reduction of vehicular traffic and transport, and to the reduction or complete stop of industrial activities given by the restrictions imposed by the authorities. As reported in Source Apportionment Study of the City of Skopje, city traffic counts for a $19-20 \%$ of the total PM emissions [11], thus even a slight reduction of work related traveling or commuting might have influenced the overall concentrations. Similar trend of reduction of $\mathrm{PM}_{10}$ by 33-41\% was reported in Milan, (Italy) study during the partial lockdown and additional 13-19\% during total lockdown; and for $\mathrm{PM}_{2.5}$, reduction from $37-44 \%$. As concluded in Milan study, small difference of PM concentrations between partial and total lockdown can be attributable due to low contribution of the industrial sector [15].

The concentration difference of PM between two periods was statistically significant for $\mathrm{PM}_{10}$ and $\mathrm{PM}_{2.5}$ in the City of Skopje $\left(41.8 \mu \mathrm{g} / \mathrm{m}^{3}\right.$ in non-COVID period and $34.1 \mu \mathrm{g} / \mathrm{m}^{3}$ in 2020 for $\mathrm{PM}_{10}$; and $26.6 \mu \mathrm{g} / \mathrm{m}^{3}$ and 22.3 $\mu \mathrm{g} / \mathrm{m}^{3}$ for $\left.\mathrm{PM}_{2.5}\right)$. It is unexpected finding for the capital city, bearing in mind the smaller difference in the other 
cities, or even increment in the $\mathrm{PM}_{2.5}$ concentrations in Kumanovo. We found that $\mathrm{PM}_{2.5}$ concentrations in Skopje are moderately correlated with carbon monoxide in all four cities $\left(r=0.51-R^{2}=0.27\right)$ and with $\mathrm{NO}_{2}$ in Skopje and Bitola $\left(r=0.61 ; R^{2}=0.37\right)$ (Table A7).

Concentration of $\mathrm{PM}_{2.5}$ and $\mathrm{PM}_{10}$ decreased by $32 \%$ and $34 \%$, respectively, have been reported in the study of Yangtze Delta River, (China) after implementations of Level I and Level II response that means particularly serious and serious level of measures according to their National Emergency Response Plan [16], and $24 \%$ reduction of $\mathrm{PM}_{2.5}$ in cities in China that have been locked down [17]. In its recent report, World Bank reported no change of $\mathrm{PM}_{2.5}$ concentrations in France, Beijing and other bigger cities in China after the lockdown, while in India and Hubei, China levels of $\mathrm{PM}_{2.5}$ were lower after the lockdown but similar trend is reported in that part of the year prior COVID-19 outbreak. The effects in Delhi, India, were visible after 10 days after the lockdown, while in Kolkata, the decline came over 3 weeks after [18].

The smaller, or lack of reductions in $\mathrm{PM}_{2.5}$ concentrations reflect the fact that " $\mathrm{PM}_{2.5}$ has a complex source structure and not all sources of $\mathrm{PM}_{2.5}$ were affected by the economic lockdown" such as natural sources, windblown dust, and dust. Secondary formed $\mathrm{PM}_{2.5}$ from precursors such as ammonia mixed with sulfur dioxide $\left(\mathrm{SO}_{2}\right)$, nitrogen dioxides $\left(\mathrm{NO}_{2}\right)$, or low range transportation are significant source of particulate matter apart from direct emissions [19]. Many reports summarized that "air quality has many components and improvements were not consistent as a result of the economic lockdown, particularly when it comes to the pollutant that is the most harmful to human health $-\mathrm{PM}_{2.5} "$ [16], [18], [19].

\section{Impact of the lockdown on the $\mathrm{NO}_{2}$, ozone and carbon monoxide}

Themostsignificantreductionoftheconcentration in the study was found in terms of $\mathrm{NO}_{2}$ concentration (by $5 \%$ in Kumanovo; $24 \%$ in Bitola; $27 \%$ in Tetovo and $31 \%$ in Skopje). The $\mathrm{NO}_{2}$ and $\mathrm{PM}_{2.5}$ concentrations correlated well $(r=0.61$ in Skopje; $r=0.78$ Tetovo; $r=$ 0.73 Kumanovo) (Table A7) which could indicate that two pollutants originate from common source. $\mathrm{NO}_{2}$, a noxious gas emitted by motor vehicles, power plants, and industrial facilities had a constant decrement of the concentrations during the analyzed period except in the 12 weeks, after the Labor Day restrictions, when the temperature increment has been reported in Skopje and Bitola (by 48-68\% respectively). The slight relaxation of the implementation of the measures and their control, as an introduction to the overall re-opening of the country to the upcoming parliamentary elections, might be the possible explanation.

In the study of Almaty, Kazakhstan, correlation was found between $\mathrm{NO}_{2}$ and carbon monoxide during COVID-19 period, but decrement of $\mathrm{NO}_{2}$ concentration was partly related to higher precipitations in the analyzed period [19]. The most prominent drop of $\mathrm{NO}_{2}$ concentration has been reported in the Yangtze River Delta Region, China as well (by $30-52 \%$ ) as a result of the stoppage of industrial activities in various enterprises. World Bank reported sharp decrement in Hubei (China), France, and India through satellite that was as nearly as those measured by ground level monitoring stations [18]. Our study findings are similar to the studies conducted in Milan, Italy [15]. Measures and lockdown implemented in Barcelona led to $\mathrm{NO}_{2}$ reduction from $47.0 \%$ to $51.4 \%$ [20], [21], similarly to other major cities such as Madrid and Seville in Spain (by 20 to 30\% after the lockdown). Furthermore, same reduction through NASA satellite has been reported in northeastern part of USA [5], [22] and Bay Area, San Francisco USA [23].

Surprisingly, in our study, we found a significant drop of the concentration of ground level ozone compared to the pre COVID-19 3-years period by $6-47 \%$ (see section Results, Table A5). Having in mind the missing meteorological data in the other cities (Tetovo and Kumanovo where the highest drop of the concentration was reported), we were not able to define the role of those factors on this decline. However, a moderate inverse correlation between ozone and $\mathrm{NO}_{2}$ levels is evident in this study and expected, due to complex photochemical reactions between nitrogen oxides and volatile organic compounds in the presence of sunlight that results with formation of ozone. Many studies have found that reduction in the level of nitrogen dioxide $\left(\mathrm{NO}_{2}\right)$ is invariably accompanied by an increase in the atmospheric concentration of $\mathrm{O}_{3}$ [17], [24], [25], [26], [27], [28]. Still, the absence of data on VOCs and benzene emissions has stopped us to make final conclusion on this. The rising of $\mathrm{O}_{3}$ is usual during spring and summer due to higher solar radiation, which promotes the photolysis of $\mathrm{NO}_{2}$ [15], [29], [30]. In our study, increment of the ozone concentration followed after the increment of the ambient temperature is evident in the $6^{\text {th }}$ and the $7^{\text {th }}$ week of the analyzed COVID-19 period (Figure 4 and Table A5).

The effect of implemented measures in Republic of Macedonia was not so homogeneous in terms of carbon monoxide concentrations. The highest drop we found was in Kumanovo (31\%), 10\% in Bitola and 4\% in Tetovo, while in Skopje, the concentrations were even higher by $3 \%$ compared to the 2017-2019. Having in mind that main sources of $\mathrm{CO}$ emissions are incomplete combustion processes (household heating, traffic etc.), in the absence of new source apportionment study and meteorological data for other two cities, it is very hard to make a final conclusion for all analyzed air pollutants including $\mathrm{CO}$.

Monitoring of air quality and pollutant concentrations along with population and health data such as fraction of population that live in areas at high levels of pollutants, incidence, hospital admission, and mortality due to respiratory and cardiovascular diseases and number of people infected by COVID-19, is very 
important to analyze the effects of long-term and shortterm effects of air pollution on the spread and outcomes of COVID-19 infections. Many studies already found conclusive data that indicate correlation between longterm and short-term pollution with the cases of COVID19 and those factors may represent a favorable context for the spread of the virus [31], [32], [33], [34], [35].

This study has some limitations. Missing continuous measurements of meteorological data in the city of Tetovo and Kumanovo could be considered as one of them. Second, "comparison between air pollution levels before and after the outbreak can be problematic because it lacks a proper counterfactual analysis" [17]. In the setting of Macedonia, this could be also a problem due to slightly decreasing trend of air pollutants over the last years caused by implementations of some measures and enforcement of environmental regulations (stricter measures for emissions from industries for example), or might be due to increased environmental public awareness. During the COVID-19 period, a complete (total) lockdown or better to say quarantine has been implemented only in one city (Debar), but absence of monitoring station nearby, small population size and density of the city, stopped us to use Debar as a control city (counterfactual).

\section{Conclusions}

Its well-known that air pollution has a various adverse health effects. It affects our mental health, cognition, productivity, has effects on morbidity and mortality and quality of our lives in general.

In our study, we have found substantial decrement of the air pollutants concentration due to reduced human activities caused by COVID-19 pandemic. Still, concentrations of particulate matter especially, remained high during lockdown, 2-3 times higher than levels considered safe by the WHO (10 $\mu \mathrm{g} / \mathrm{m}^{3}$ for the annual mean) [36]. That indicates there are other pollution sources devastating the air that we breathe. Our findings could have an important implication on future policy making processes. Still, there is a need of cost-benefit study to assess economic cost due to lockdown in Republic of Macedonia. According to the experiences from China, similar levels of air quality improvement can be achieved at a much lower cost, for example, restrictions on gasoline fuel standards (more stringent standards), introducing control zones in cities, implementation of stringent short-term environmental regulations during some bigger events or gathering of people, stringent control of emissions from coal-fired power plants, etc. As is concluded in China studies, "is highly inefficient to use city lockdowns to reduce pollution, and many other, cheaper, ways to achieve the same environmental target exist" [17]. Although beneficial to human health, economic implications of the lockdown could have a negative impact on the health as well.

Aggregating and analyzing morbidity and mortality data timely will enable to assess the overall health burden of lockdown. Further studies regarding chemical composition of particulate matter in terms of polycyclic aromatic hydrocarbons (single molecules and their ratios), nitro-compounds, metals, and semimetals might lead to a more accurate description of this or similar phenomena.

Finally, from this unexpected situation, we should learn how to reduce pollution on long-term basis implementing more sustainable practices and behaviors in our daily routine.

\section{Acknowledgment}

We would like to acknowledge with appreciation the cooperation with Mr. Nikola Golubov and Mrs. Aneta Stefanovska from Macedonian Environment Information Center, Ministry of Environment and Physical Planning for providing environmental data and their valuable suggestions.

\section{References}

1. World Health Organization. Coronavirus (COVID-19) Situation Report-108. Geneva: World Health Organization; 2020. Available from: https://www.who.int/docs/default-source/ coronaviruse/situation-reports/20200507covid-19-sitrep-108. pdf?sfvrsn=44cc8ed8_2. [Last accessed on 2020 Jun 17].

2. World Health Organization. Coronavirus Disease (COVID-19) Outbreak. Geneva: World Health Organization. Available from: https://www.euro.who.int/en/health-topics/health-emergencies/ coronavirus-covid-19/news/news/2020/01/2019-ncov-outbreakis-an-emergency-of international-concern. [Last accessed on 2020 Jun 22]

3. Government of Republic of Macedonia. Official information on Coronavirus in North Macedonia. Available from: https://www. koronavirus.gov.mk.

4. Wu X, Nethery RC, Sabath MB, Braun D, Dominici F. Exposure to air pollution and COVID-19 mortality in the United States: A nationwide cross-sectional study. MedRxiv. 2020; 04.05.20054502. https://doi.org/10.1101/2020.04.05.20054502

5. National Aeronautics and SpaceAdministration. Earth Observatory. Washington, DC, United States: National Aeronautics and Space Administration. Available from: https://www.earthobservatory. nasa.gov/images/146362/airborne-nitrogen-dioxide-plummetsover-china. [Last accessed on 2020 May 14].

6. European Space Agency; 2020. Available from: https://www.esa int/Applications/Observing_the_Earth/Copernicus/Sentinel-5P. [Last accessed on 2020 May 14].

7. Chakraborty I, Maity P. COVID-19 outbreak: Migration, effects on society, global environment and prevention. Sci Total Environ. 2020;728:138882. https://doi.org/10.1016/j. scitotenv.2020.138882 


\section{PMid:32335410}

8. The Guardian. Nature is Taking Back Venice: Wildlife Returns to Tourist-free City. United Kingdom: The Guardian; 2020. Available from: https://www.theguardian.com/environment/2020/mar/20/ nature-is-taking-back-venice-wildlife-returns-to-tourist-free-city. [Last accessed on 2020 Apr 22].

9. Paital B. Nurture to nature via COVID-19, a self-regenerating environmental strategy of environment in global context. Sci Total Environ. 2020;729:139088. https://doi.org/10.1016/j. scitotenv.2020.139088

PMid:32388136

10. State Statistical Office. MakStat Database. Estimation of Population. Available from: http://www.makstat.stat.gov.mk/ PXWeb/pxweb/en/MakStat/?rxid=46ee0f64-2992-4b45-a2d9cb4e5f7ec5ef. [Last accessed on 2020 May 03].

11. MEPP, Macedonian Environmental Information Center. Macedonian Air Quality Assessment Report for the Period Canada: MEPP; 2015

12. State Statistical Office. Municipalities and Settlements. Available from: http://www.stat.gov.mk/OpstiniNM_en.aspx. [Last accessed on 2020 May 03]

13. Ghasemi A, ZahediasI S. Normality tests for statistical analysis: A guide for non-statisticians. Int $\mathrm{J}$ Endocrinol Metabol. 2012;10(2):486-9. https://doi.org/10.5812/ijem.3505 PMid:23843808

14. Schmider E, Ziegler M, Danay E, Beyer L, Buhner M. Is it really robust? Reinvestigating the robustness of ANOVA against violations of the normal distribution assumption. Methodology. 2010;6(4):147-51. https://doi.org/10.1027/1614-2241/a000016

15. Collivignarelli MC, AbbàA, Bertanza G, Pedrazzani R, Ricciardi $P$, Miino MC. Lockdown for COVID-2019 in Milan: What are the effects on air quality? Sci Total Environ. 2020;732:139280. https://doi.org/10.1016/j.scitotenv.2020.139280 PMid:32402928

16. Li L, Li Q, Huang L, Wang Q, Zhu A, Xu J, et al. Air quality changes during the COVID-19 lockdown over the Yangtze River Delta region: An insight into the impact of human activity pattern changes on air pollution variation. Sci Total Environ. 2020;732:139282. https://doi.org/10.1016/j. scitotenv.2020.139282 PMid:32413621

17. He G, Pan Y, Tanaka T. The short-term impacts of COVID-19 lockdown on urban air pollution in China. Nat Sustain. 2020 https://doi.org/10.1038/s41893-020-0581-y

18. The World Bank. Air Pollution: Locked Down by COVID19 but Not Arrested. Washington, DC, United States: The World Bank; 2020. Available from: https://www. worldbank.org/en/news/immersive-story/2020/07/01/ air-pollution-locked-down-by-covid-19-but-not-arrested.

19. Kerimray A, Baimatova N, Ibragimova OP, Bukenov B Kenessov B, Plotitsyn $\mathrm{P}$, et al. Assessing air quality changes in large cities during COVID-19 lockdowns: The impacts of traffic-free urban conditions in Almaty, Kazakhstan. Sci Total Environ. 2020;730:139179. https://doi.org/10.1016/j. scitotenv.2020.139179

PMid:32387822

20. Tobías A. Evaluation of the lockdowns for the SARS-CoV-2 epidemic in Italy and Spain after one month follow up. Sci Total Environ. 2020;725:138539. https://doi.org/10.1016/j. scitotenv.2020.138539

PMid:32304973

21. Tobías A, Carnerero C, Reche C, Massagué J, Via M, Minguillón MC, et al. Changes in air quality during the lockdown in Barcelona (Spain) one month into the SARS-CoV-2 epidemic. Sci Total Environ. 2020;726:138540. https://doi.org/10.1016/j. scitotenv.2020.138540

\section{PMid:32302810}

22. Muhammad S, Long $X$, Salman M. COVOD-19 pandemic and environmental pollution: A blessing in disguise? Sci Total Environ. 2020;728:138820. https://doi.org/10.1016/j. scitotenv.2020.138820

PMid:32334164

23. Lunden M, Thurlow M. Bay Area air Pollution During COVID-19. San Francisco, California: Aclima; 2020. Available from: https:// www.blog.aclima.io/bay-area-air-pollution-during-covid-192edd2946e759. [Last accessed on 2020 Apr 28].

24. Mazzeo NA, Venegas LE, Choren H. Analysis of NO, NO2, O3 and NOx concentrations measured at a green area of Buenos Aires city during wintertime. Atmos Environ. 2005;39:3055-68. https://doi.org/10.1016/j.atmosenv.2005.01.029

25. Aguedo-Castaneda DM, Teixeira EC, Pereira FN. Time-series analysis of surface ozone and nitrogen oxides concentrations in an urban area at Brazil. Atmos Pollut Res. 2014;5(3):411-20. https://doi.org/10.5094/apr.2014.048

26. Hagenbjork A, Malmqvist E, Mattisson K, Sommar JN, Modig L. The spatial variation of $\mathrm{O}_{3}, \mathrm{NO}, \mathrm{NO}_{2}$ and $\mathrm{NO}_{\mathrm{x}}$ and the relation between them in Swedish cities. Environ Monit Assess. 2017;189(4):161. https://doi.org/10.1007/s10661-017-5872-z PMid:28290139

27. Han S, Bian H, Feng Y, Liu A, Li X, Zeng F, et al. Analysis of the relationship between $\mathrm{O}_{3}, \mathrm{NO}$ and $\mathrm{NO}_{2}$ in Tianjin, China. Aerosol Air Qual Res. 2011;11:128-39. https://doi.org/10.4209/ aaqr.2010.07.0055

28. Sillman $\mathrm{S}$. The relation between ozone, $\mathrm{NO}_{\mathrm{x}}$ and hydrocarbons in urban and polluted rural environments. Atmos Environ. 1999;33:1821-45. https://doi.org/10.1016/ s1352-2310(98)00345-8

29. Escudero M, Segers A, Kranenburg R, Querol X, Alastuey A, Borge $\mathrm{R}$, et al. Analysis of summer $\mathrm{O}_{3}$ in the Madrid Air basin with the LOTOS-EUROS chemical transport model. Atmos Chem Phys. 2019;19:14211-32. https://doi.org/10.5194/ acp-19-14211-2019

30. Wang $\mathrm{P}$, Qiao $\mathrm{X}$, Zhang $\mathrm{H}$. Modeling PM2.5 and $\mathrm{O}_{3}$ with aerosol feedbacks using WRF/Chem over the Sichuan Basin, Southwestern China. Chemosphere. 2020;254:126735. https:// doi.org/10.1016/j.chemosphere.2020.126735 PMid:32325353

31. Comunian S, Dongo D, Milani C. Air pollution and COVID-19: The role of particulate matter in the spread and increase of COVID19's morbidity and mortality. Int J Environ Res Public Health. 2020;17(12):4487. https://doi.org/10.3390/ijerph17124487 PMid: 32580440

32. Pansini R, Fornacca D. Initial evidence of higher morbidity and mortality due to SARS-CoV-2 in regions with lower air quality. MedRxiv. 2020; 04.04.20053595. https://doi. org/10.1101/2020.04.04.20053595

33. Conticini E, Frediani B, Caro D. Can atmospheric pollution be considered a co-factor in extremely high level of SARS-CoV-2 lethality in Northern Italy? Environ Pollut. 2020;261:114465. https://doi.org/10.1016/j.envpol.2020.114465 PMid:32268945

34. Fattorini $D$, Regoli F. Role of the chronic air pollution levels in the covid-19 outbreak risk in Italy. Environ Pollut. 2020;264:114732. https://doi.org/10.1016/j.envpol.2020.114732 PMid:32387671

35. Pansini R, Fornacca D. Higher virulence of COVID19 in the air-polluted regions of eight severely affected countries. MedRxiv. 2020; 04.30.20086496. https://doi. org/10.1101/2020.04.30.20086496

36. World Health Organization. Air Quality Guidelines for Particulate Matter, Ozone, Nitrogen Dioxide and Sulfur Dioxide. Geneva: World Health Organization; 2005. 


\section{Appendix}

Table A1: Average temperature of ambient air and \% change compared with previous week of the COVID-19 period

\begin{tabular}{|c|c|c|c|c|c|c|c|c|c|c|c|c|c|c|c|}
\hline $\begin{array}{l}\text { Meteorological } \\
\text { factor }\end{array}$ & Period & 22 February & 1 March & 8 March & 15 March & 22 March & 29 March & 5 April & 12 April & 19 April & 26 April & 3 May & 10 May & 17 May & 24 May \\
\hline \multicolumn{16}{|c|}{ Temperature $\left({ }^{\circ} \mathrm{C}\right)$} \\
\hline \multirow[t]{3}{*}{ Skopje } & $2017-2019$ & 5.2 & 9.0 & 10.2 & 11.7 & 10.4 & 14.2 & 14.3 & 15.3 & 14.7 & 18.6 & 17.6 & 18.1 & 18.9 & 20.2 \\
\hline & Covid-19, 2020 & 6.6 & 8.9 & 10.4 & 9.8 & 5.4 & 6.9 & 12.7 & 13.1 & 13.2 & 15.8 & 14.3 & 21.3 & 20.2 & 15.5 \\
\hline & & & $36 \%$ & $17 \%$ & $-6 \%$ & $-45 \%$ & $29 \%$ & $83 \%$ & $3 \%$ & $0 \%$ & $20 \%$ & $-9 \%$ & $48 \%$ & $-5 \%$ & $-23 \%$ \\
\hline \multirow[t]{3}{*}{ Bitola } & 2017-2019 & 2.7 & 6.9 & 7.4 & 9.3 & 7.2 & 10.2 & 10.8 & 13.4 & 11.2 & 16.1 & 13.9 & 14.5 & 15.1 & 16.1 \\
\hline & Covid-19, 2020 & 6.64 & 8.32 & 8.47 & 6.72 & 3.80 & 3.64 & 9.29 & 11.64 & 11.21 & 14.46 & 12.27 & 20.64 & 17.51 & 12.59 \\
\hline & & & $25 \%$ & $2 \%$ & $-21 \%$ & $-43 \%$ & $-4 \%$ & $155 \%$ & $25 \%$ & $-4 \%$ & $29 \%$ & $-15 \%$ & $68 \%$ & $-15 \%$ & $-28 \%$ \\
\hline \multicolumn{16}{|l|}{ Humidity (\%) } \\
\hline \multirow[t]{3}{*}{ Skopje } & 2017-2019 & & 64.8 & 64.7 & 63.6 & 59.3 & 58.3 & 49.3 & 61.9 & 60.9 & 51.8 & 58.9 & 64.4 & 66.5 & 65.1 \\
\hline & Covid-19, 2020 & & 51.9 & 53.8 & 64.7 & 55.6 & 83.4 & 72.1 & 46.9 & 52.9 & 67.2 & 60.0 & 57.9 & 54.7 & 61.6 \\
\hline & & & & $4 \%$ & $20 \%$ & $-14 \%$ & $50 \%$ & $-14 \%$ & $-35 \%$ & $13 \%$ & $27 \%$ & $-11 \%$ & $-4 \%$ & $-5 \%$ & $13 \%$ \\
\hline \multirow[t]{3}{*}{ Bitola } & 2017-2019 & & 71.2 & 60.2 & 60.9 & 55.1 & 63.8 & 55.4 & 67.0 & 63.7 & 60.5 & 56.6 & 63.7 & 69.3 & 67.5 \\
\hline & Covid-19, 2020 & & 64.0 & 68.6 & 71.9 & 59.4 & 85.0 & 83.0 & 52.9 & 50.7 & 65.9 & 56.6 & 57.7 & 43.1 & 60.4 \\
\hline & & & & $7 \%$ & $5 \%$ & $-17 \%$ & $43 \%$ & $-2 \%$ & $-36 \%$ & $-4 \%$ & $30 \%$ & $-14 \%$ & $2 \%$ & $-25 \%$ & $40 \%$ \\
\hline \multicolumn{16}{|c|}{ Wind speed $(\mathrm{m} / \mathrm{s})$} \\
\hline \multirow{2}{*}{ Skopje } & $2017-2019$ & 0.8 & 0.4 & 0.8 & 0.6 & 0.8 & 0.7 & 0.7 & 0.6 & 0.9 & 0.5 & 0.6 & 0.5 & 0.5 & 0.5 \\
\hline & Covid-19, 2020 & 0.5 & 0.4 & 0.6 & 0.6 & 0.6 & 0.9 & no data & & & & & & & \\
\hline \multirow[t]{3}{*}{ Bitola } & 2017-2019 & 0.4 & 0.3 & 0.4 & 0.4 & 0.4 & 0.4 & 0.3 & 0.3 & 0.3 & 0.3 & 0.2 & 0.2 & 0.2 & 0.2 \\
\hline & Covid-19, 2020 & 0.2 & 0.3 & 0.4 & 0.2 & 0.3 & 0.2 & 0.4 & 0.2 & 0.3 & 0.4 & 0.3 & 0.1 & 0.1 & 0.1 \\
\hline & & & $12 \%$ & $32 \%$ & $-36 \%$ & $25 \%$ & $-30 \%$ & $80 \%$ & $-32 \%$ & $30 \%$ & $14 \%$ & $-28 \%$ & $-56 \%$ & $0 \%$ & $25 \%$ \\
\hline
\end{tabular}

Table A2: Average concentration of $\mathrm{PM}_{10}\left(\mu \mathrm{g} / \mathrm{m}^{3}\right)$ and \% change compared with previous week of the COVID-19 period

\begin{tabular}{|c|c|c|c|c|c|c|c|c|c|c|c|c|c|c|c|c|}
\hline City & Period & 22 February & 1 March & 8 March & 15 March & 22 March & 29 March & 5 April & 12 April & 19 April & 26 April & 3 May & 10 May & 17 May & 24 May & $\begin{array}{l}\text { Average of the } \\
\text { two periods }\end{array}$ \\
\hline \multirow{3}{*}{ Skopje } & $2017-2019$ & 66.3 & 62.6 & 44.7 & 48.4 & 47.1 & 41.4 & 32.4 & 37.9 & 35.0 & 43.2 & 34.9 & 29.2 & 31.1 & 30.6 & 41.8 \\
\hline & COVID-19, 2020 & 49.6 & 41.6 & 37.1 & 44.2 & 40.8 & 39.8 & 32.4 & 30.2 & 22.6 & 23.2 & 21.2 & 39.5 & 39.2 & 16.3 & 34.1 \\
\hline & & & $-16 \%$ & $-11 \%$ & $19 \%$ & $-8 \%$ & $-2 \%$ & $-19 \%$ & $-7 \%$ & $-25 \%$ & $3 \%$ & $-9 \%$ & $87 \%$ & $-1 \%$ & $-58 \%$ & $-18 \%$ \\
\hline \multirow{3}{*}{ Bitola } & 2017-2019 & 55.5 & 46.3 & 31.8 & 46.4 & 38.4 & 37.1 & 36.6 & 39.3 & 36.9 & 49.7 & 29.3 & 28.3 & 25.5 & 22.1 & 37.4 \\
\hline & COVID-19, 2020 & 52.6 & 38.4 & 36.3 & 44.4 & 32.1 & 56.3 & 38.1 & 30.7 & 25.1 & 20.7 & 17.7 & 49.3 & 44.9 & 15.2 & 35.8 \\
\hline & & & $-27 \%$ & $-5 \%$ & $22 \%$ & $-28 \%$ & $76 \%$ & $-32 \%$ & $-19 \%$ & $-18 \%$ & $-18 \%$ & $-15 \%$ & $189 \%$ & $-9 \%$ & $-66 \%$ & $-4 \%$ \\
\hline \multirow[t]{3}{*}{ Tetovo } & 2017-2019 & 52.7 & 57.5 & 42.3 & 47.0 & 46.8 & 41.2 & 41.2 & 38.6 & 33.3 & 45.5 & 37.7 & 34.2 & 24.9 & 29.0 & 40.8 \\
\hline & COVID-19, 2020 & 58.7 & 56.3 & 40.9 & 47.6 & 39.4 & 51.9 & 36.9 & 36.4 & 26.0 & 23.9 & 21.6 & 44.1 & 42.1 & 20.1 & 39.0 \\
\hline & & & $-4 \%$ & $-27 \%$ & $16 \%$ & $-17 \%$ & $32 \%$ & $-29 \%$ & $-1 \%$ & $-29 \%$ & $-8 \%$ & $-10 \%$ & $104 \%$ & $-5 \%$ & $-52 \%$ & $-5 \%$ \\
\hline \multirow{2}{*}{ Kumanovo } & 2017-2019 & 76.6 & 75.9 & 57.3 & 57.6 & 50.3 & 52.5 & 33.8 & 36.9 & 38.7 & 45.9 & 33.3 & 28.8 & 27.6 & 25.0 & 45.7 \\
\hline & COVID-19, 2020 & 63.6 & 50.3 & 50.4 & 59.9 & 50.1 & 50.4 & 36.9 & 41.6 & 31.5 & 25.6 & 25.7 & 41.9 & 38.6 & 19.7 & 41.9 \\
\hline & & & $-21 \%$ & $0 \%$ & $19 \%$ & $-16 \%$ & $1 \%$ & $-27 \%$ & $13 \%$ & $-24 \%$ & $-19 \%$ & $0 \%$ & $63 \%$ & $-8 \%$ & $-49 \%$ & $-8 \%$ \\
\hline
\end{tabular}

Table A3: Average concentration of $\mathrm{PM}_{2.5}\left(\mu \mathrm{g} / \mathrm{m}^{3}\right)$ and \% change compared with previous week of the COVID-19 period

\begin{tabular}{|c|c|c|c|c|c|c|c|c|c|c|c|c|c|c|c|c|}
\hline City & Period & February 22 & March 1 & March 8 & March 15 & March 22 & March 29 & April 5 & April 12 & April 19 & April 26 & May 3 & May 10 & May 17 & May 24 & $\begin{array}{l}\text { Average of the } \\
\text { two periods }\end{array}$ \\
\hline \multirow[t]{2}{*}{ Skopje } & $2017-2019$ & 41.3 & 42.0 & 29.2 & 31.5 & 32.8 & 28.3 & 21.5 & 23.5 & 23.9 & 23.8 & 21.1 & 18.1 & 18.7 & 16.3 & 26.6 \\
\hline & COVID-19, 2020 & 31.3 & $\begin{array}{l}25.6 \\
-18 \%\end{array}$ & $\begin{array}{l}21.9 \\
-15 \%\end{array}$ & $\begin{array}{l}27.8 \\
27 \%\end{array}$ & $\begin{array}{l}25.7 \\
-8 \%\end{array}$ & $\begin{array}{l}24.5 \\
-5 \%\end{array}$ & $\begin{array}{l}20.7 \\
-15 \%\end{array}$ & $\begin{array}{l}22.0 \\
6 \%\end{array}$ & $\begin{array}{l}16.1 \\
-27 \%\end{array}$ & $\begin{array}{l}16.2 \\
1 \%\end{array}$ & $\begin{array}{l}16.8 \\
4 \%\end{array}$ & $\begin{array}{l}27.1 \\
61 \%\end{array}$ & $\begin{array}{l}23.9 \\
-12 \%\end{array}$ & $\begin{array}{l}12.5 \\
-48 \%\end{array}$ & $\begin{array}{l}22.3 \\
-16 \%\end{array}$ \\
\hline \multirow[t]{2}{*}{ Bitola } & 2018-2019 & 41.9 & 41.0 & 21.0 & 25.3 & 35.4 & 16.9 & 19.4 & 23.8 & 14.3 & 18.6 & 18.9 & 13.4 & 14.1 & 13.2 & 22.6 \\
\hline & COVID-19, 2020 & 34.5 & $\begin{array}{l}26.4 \\
-24 \%\end{array}$ & $\begin{array}{l}25.2 \\
-4 \%\end{array}$ & $\begin{array}{l}30.6 \\
21 \%\end{array}$ & $\begin{array}{l}27.9 \\
-9 \%\end{array}$ & $\begin{array}{l}46.7 \\
67 \%\end{array}$ & $\begin{array}{l}24.2 \\
-48 \%\end{array}$ & $\begin{array}{l}18.3 \\
-24 \%\end{array}$ & $\begin{array}{l}16.2 \\
-11 \%\end{array}$ & $\begin{array}{l}11.8 \\
-27 \%\end{array}$ & $\begin{array}{l}9.5 \\
-19 \%\end{array}$ & $\begin{array}{l}13.3 \\
40 \%\end{array}$ & $\begin{array}{l}15.8 \\
19 \%\end{array}$ & $\begin{array}{l}9.2 \\
-42 \%\end{array}$ & $\begin{array}{l}22.1 \\
-2 \%\end{array}$ \\
\hline \multirow[t]{2}{*}{ Tetovo } & $\begin{array}{l}\text { 2018-2019 } \\
\text { COVID-19, } 2020\end{array}$ & $\begin{array}{l}44.5 \\
44.3\end{array}$ & $\begin{array}{l}57.6 \\
43.4\end{array}$ & $\begin{array}{l}31.3 \\
29.1\end{array}$ & $\begin{array}{l}37.1 \\
34.6\end{array}$ & $\begin{array}{l}41.3 \\
34.3\end{array}$ & $\begin{array}{l}28.7 \\
42.0\end{array}$ & $\begin{array}{l}24.2 \\
25.2\end{array}$ & $\begin{array}{l}25.3 \\
24.9\end{array}$ & $\begin{array}{l}20.3 \\
18.6\end{array}$ & $\begin{array}{l}25.2 \\
14.8\end{array}$ & $\begin{array}{l}24.1 \\
13.1\end{array}$ & $\begin{array}{l}16.1 \\
17.3\end{array}$ & $\begin{array}{l}14.8 \\
22.3\end{array}$ & $\begin{array}{l}18.0 \\
14.2\end{array}$ & $\begin{array}{l}29.2 \\
27.0\end{array}$ \\
\hline & & & $-2 \%$ & $-33 \%$ & $19 \%$ & $-1 \%$ & $23 \%$ & $-40 \%$ & $-1 \%$ & $-25 \%$ & $-21 \%$ & $-11 \%$ & $32 \%$ & $29 \%$ & $-36 \%$ & $-7 \%$ \\
\hline Kumanovo & $\begin{array}{l}\text { 2018-2019 } \\
\text { COVID-19, } 2020\end{array}$ & $\begin{array}{l}35.8 \\
43.8\end{array}$ & $\begin{array}{l}56.5 \\
32.9 \\
-25 \%\end{array}$ & $\begin{array}{l}40.7 \\
35.7 \\
8 \%\end{array}$ & $\begin{array}{l}33.6 \\
42.5 \\
19 \%\end{array}$ & $\begin{array}{l}32.8 \\
40.5 \\
-5 \%\end{array}$ & $\begin{array}{l}33.1 \\
38.1 \\
-6 \%\end{array}$ & $\begin{array}{l}20.5 \\
24.5 \\
-36 \%\end{array}$ & $\begin{array}{l}21.9 \\
29.4 \\
20 \%\end{array}$ & $\begin{array}{l}20.3 \\
23.3 \\
-21 \%\end{array}$ & $\begin{array}{l}18.1 \\
16.8 \\
-28 \%\end{array}$ & $\begin{array}{l}17.0 \\
16.8 \\
0 \%\end{array}$ & $\begin{array}{l}12.6 \\
18.0 \\
8 \%\end{array}$ & $\begin{array}{l}11.6 \\
18.5 \\
2 \%\end{array}$ & $\begin{array}{l}12.4 \\
13.3 \\
-28 \%\end{array}$ & $\begin{array}{l}26.2 \\
28.2 \\
7 \%\end{array}$ \\
\hline
\end{tabular}

Table A4: Average concentration of $\mathrm{NO}_{2}\left(\mu \mathrm{g} / \mathrm{m}^{3}\right)$ and $\%$ change compared with previous week of the COVID-19 period

\begin{tabular}{|c|c|c|c|c|c|c|c|c|c|c|c|c|c|c|c|c|}
\hline City & Period & 22 February & 1 March & 8 March & 15 March & 22 March & 29 March & 5 April & 12 April & 19 April & 26 April & 3 May & 10 May & 17 May & 24 May & $\begin{array}{l}\text { Average of the } \\
\text { two periods }\end{array}$ \\
\hline \multirow[t]{3}{*}{ Skopje } & $2017-2019$ & 29.7 & 33.7 & 31.4 & 32.9 & 31.4 & 28.0 & 21.7 & 23.2 & 22.9 & 21.1 & 21.8 & 20.8 & 23.2 & 23.5 & 26.1 \\
\hline & COVID-19, 2020 & 31.8 & 33.1 & 27.6 & 26.1 & 22.6 & 16.5 & 13.4 & 11.8 & 10.1 & 11.4 & 12.1 & 12.4 & 12.6 & 12.4 & 18.1 \\
\hline & & & $4 \%$ & $-17 \%$ & $-5 \%$ & $-13 \%$ & $-27 \%$ & $-19 \%$ & $-12 \%$ & $-15 \%$ & $13 \%$ & $7 \%$ & $2 \%$ & $2 \%$ & $-1 \%$ & $-31 \%$ \\
\hline \multirow[t]{3}{*}{ Bitola } & 2017-2019 & 16.6 & 25.0 & 12.7 & 15.8 & 15.3 & 15.2 & 14.8 & 13.2 & 13.2 & 13.9 & 11.6 & 13.1 & 13.0 & 11.4 & 14.6 \\
\hline & COVID-19, 2020 & 18.1 & 16.6 & 14.9 & 16.7 & 8.8 & 14.5 & 9.7 & 8.6 & 6.5 & 7.7 & 7.0 & 10.8 & 8.6 & 6.7 & 11.1 \\
\hline & & & $-9 \%$ & $-10 \%$ & $12 \%$ & $-47 \%$ & $64 \%$ & $-33 \%$ & $-11 \%$ & $-25 \%$ & $20 \%$ & $-10 \%$ & $54 \%$ & $-20 \%$ & $-22 \%$ & $-24 \%$ \\
\hline \multirow[t]{3}{*}{ Tetovo } & 2018-2019 & 23.9 & 39.4 & 29.6 & 29.2 & 29.5 & 28.7 & 23.7 & 24.7 & 23.6 & 20.7 & 20.8 & 19.5 & 17.5 & 16.2 & 24.8 \\
\hline & COVID-19, 2020 & 33.7 & 33.4 & 25.6 & 17.3 & 15.7 & 20.5 & 16.2 & 14.1 & 10.7 & 13.4 & 13.8 & 14.8 & 15.1 & 10.2 & 18.2 \\
\hline & & & $-1 \%$ & $-23 \%$ & $-33 \%$ & $-9 \%$ & $31 \%$ & $-21 \%$ & $-13 \%$ & $-24 \%$ & $25 \%$ & $3 \%$ & $8 \%$ & $2 \%$ & $-32 \%$ & $-27 \%$ \\
\hline \multirow[t]{3}{*}{ Kumanovo } & 2018-2019 & 19.4 & 32.2 & 29.8 & 22.6 & 19.9 & 25.4 & 24.1 & 18.3 & 20.5 & 16.9 & 15.4 & 13.8 & 13.5 & 11.5 & 20.2 \\
\hline & COVID-19, 2020 & 23.6 & 25.4 & 20.0 & 24.8 & 17.5 & 17.3 & 22.6 & 23.4 & 15.7 & 12.8 & 16.8 & 18.5 & 15.0 & 15.6 & 19.2 \\
\hline & & & $8 \%$ & $-22 \%$ & $24 \%$ & $-29 \%$ & $-1 \%$ & $30 \%$ & $4 \%$ & $-33 \%$ & $-18 \%$ & $32 \%$ & $10 \%$ & $-19 \%$ & $4 \%$ & $-5 \%$ \\
\hline
\end{tabular}


Table A5: Average concentration of $\mathrm{O}_{3}\left(\mu \mathrm{g} / \mathrm{m}^{3}\right)$ and $\%$ change compared with previous week of the COVID-19 period

\begin{tabular}{|c|c|c|c|c|c|c|c|c|c|c|c|c|c|c|c|c|}
\hline City & Period & 22 February & 1 March & 8 March & 15 March & 22 March & 29 March & 5 April & 12 April & 19 April & 26 April & 3 May & 10 May & 17 May & 24 May & $\begin{array}{l}\text { Average of the } \\
\text { two periods }\end{array}$ \\
\hline \multirow[t]{3}{*}{ Skopje } & $2017-2019$ & 32.4 & 32.8 & 33.4 & 31.7 & 40.4 & 47.4 & 40.6 & 39.9 & 45.9 & 40.0 & 42.2 & 40.7 & 43.1 & 43.3 & 39.6 \\
\hline & COVID-19, 2020 & 27.0 & 21.1 & 28.3 & 30.8 & 18.4 & 37.7 & 48.1 & 44.6 & 43.5 & 42.3 & 45.0 & 45.0 & 43.0 & 48.5 & 37.4 \\
\hline & & & $-22 \%$ & $34 \%$ & $9 \%$ & $-40 \%$ & $105 \%$ & $27 \%$ & $-7 \%$ & $-2 \%$ & $-3 \%$ & $6 \%$ & $0 \%$ & $-4 \%$ & $13 \%$ & $-6 \%$ \\
\hline \multirow{3}{*}{ Bitola } & 2017-2019 & 46.1 & 54.6 & 58.2 & 55.3 & 56.1 & 63.6 & 53.4 & 65.7 & 66.0 & 63.4 & 70.5 & 61.9 & 61.0 & 58.7 & 59.6 \\
\hline & COVID-19, 2020 & 40.1 & 42.9 & 40.4 & 42.4 & 42.4 & 44.6 & 56.1 & 54.3 & 50.4 & 58.5 & 57.4 & 53.5 & 51.6 & 51.2 & 49.0 \\
\hline & & & $7 \%$ & $-6 \%$ & $5 \%$ & $0 \%$ & $5 \%$ & $26 \%$ & $-3 \%$ & $-7 \%$ & $16 \%$ & $-2 \%$ & $-7 \%$ & $-4 \%$ & $-1 \%$ & $-18 \%$ \\
\hline \multirow[t]{3}{*}{ Tetovo } & 2017-2019 & 33.8 & 33.1 & 36.2 & 35.4 & 39.9 & 45.3 & 35.3 & 38.7 & 44.3 & 45.3 & 45.5 & 42.5 & 51.8 & 53.7 & 41.5 \\
\hline & COVID-19, 2020 & 17.7 & 10.9 & 18.2 & 25.3 & 10.2 & 21.0 & 38.2 & 33.3 & 23.5 & 33.0 & 29.2 & 33.7 & 26.4 & 28.2 & 24.9 \\
\hline & & & $-39 \%$ & $68 \%$ & $40 \%$ & $-60 \%$ & $107 \%$ & $82 \%$ & $-13 \%$ & $-29 \%$ & $40 \%$ & $-12 \%$ & $15 \%$ & $-22 \%$ & $7 \%$ & $-40 \%$ \\
\hline \multirow{3}{*}{ Kumanovo } & 2018-2019 & 37.2 & 24.4 & 31.2 & 37.0 & 47.5 & 55.0 & 31.9 & 30.3 & 46.0 & 38.2 & 38.3 & 35.6 & 41.2 & 40.0 & 38.1 \\
\hline & COVID-19, 2020 & 19.2 & 17.0 & 15.9 & 22.3 & 12.0 & 19.0 & 34.1 & 25.0 & 16.9 & 16.9 & 24.2 & 21.6 & 19.2 & 22.3 & 20.4 \\
\hline & & & $-12 \%$ & $-6 \%$ & $40 \%$ & $-46 \%$ & $58 \%$ & $80 \%$ & $-27 \%$ & $-32 \%$ & $0 \%$ & $43 \%$ & $-11 \%$ & $-11 \%$ & $16 \%$ & $-47 \%$ \\
\hline
\end{tabular}

Table A6: Average concentration of $\mathrm{CO}\left(\mathrm{mg} / \mathrm{m}^{3}\right)$ and \% change compared with previous week of the COVID-19 period

\begin{tabular}{|c|c|c|c|c|c|c|c|c|c|c|c|c|c|c|c|c|}
\hline City & Period & 22 February & 1 March & 8 March & 15 March & 22 March & 29 March & 5 April & 12 April & 19 April & 26 April & 3 May & 10 May & 17 May & 24 May & $\begin{array}{l}\text { Average of the } \\
\text { two periods }\end{array}$ \\
\hline \multirow[t]{3}{*}{ Skopje } & $2017-2019$ & 0.85 & 0.69 & 0.52 & 0.58 & 0.50 & 0.43 & 0.39 & 0.40 & 0.34 & 0.32 & 0.29 & 0.28 & 0.31 & 0.31 & 0.44 \\
\hline & COVID-19, 2020 & 0.92 & 0.69 & 0.60 & 0.66 & 0.52 & 0.44 & 0.35 & 0.37 & 0.25 & 0.28 & 0.35 & 0.34 & 0.30 & 0.32 & 0.46 \\
\hline & & & $-25 \%$ & $-13 \%$ & $10 \%$ & $-22 \%$ & $-15 \%$ & $-19 \%$ & $4 \%$ & $-33 \%$ & $14 \%$ & $24 \%$ & $-4 \%$ & $-10 \%$ & $4 \%$ & $3 \%$ \\
\hline \multirow[t]{3}{*}{ Bitola } & 2017-2019 & 0.67 & 0.58 & 0.43 & 0.47 & 0.41 & 0.32 & 0.36 & 0.28 & 0.28 & 0.23 & 0.26 & 0.26 & 0.22 & 0.26 & 0.36 \\
\hline & COVID-19, 2020 & 0.88 & 0.36 & 0.38 & 0.46 & 0.30 & 0.49 & 0.25 & 0.20 & 0.20 & 0.19 & 0.17 & 0.24 & 0.23 & 0.15 & 0.32 \\
\hline & & & $-59 \%$ & $6 \%$ & $20 \%$ & $-33 \%$ & $61 \%$ & $-49 \%$ & $-20 \%$ & $-1 \%$ & $-2 \%$ & $-10 \%$ & $38 \%$ & $-3 \%$ & $-34 \%$ & $-10 \%$ \\
\hline \multirow[t]{3}{*}{ Tetovo } & $2017-2019$ & 0.69 & 0.78 & 0.46 & 0.55 & 0.48 & 0.36 & 0.29 & 0.29 & 0.26 & 0.23 & 0.26 & 0.21 & 0.19 & 0.19 & 0.37 \\
\hline & COVID-19, 2020 & 0.91 & 0.63 & 0.42 & 0.24 & 0.38 & 0.42 & 0.27 & 0.31 & 0.29 & 0.28 & 0.29 & 0.26 & 0.19 & 0.14 & 0.36 \\
\hline & & & $-31 \%$ & $-34 \%$ & $-42 \%$ & $58 \%$ & $9 \%$ & $-34 \%$ & $13 \%$ & $-7 \%$ & $-4 \%$ & $3 \%$ & $-10 \%$ & $-28 \%$ & $-23 \%$ & $-4 \%$ \\
\hline \multirow[t]{3}{*}{ Kumanovo } & 2017-2019 & 0.96 & 1.15 & 0.77 & 0.69 & 0.55 & 0.48 & 0.64 & 0.26 & 0.25 & 0.27 & 0.34 & 0.23 & 0.20 & 0.17 & 0.50 \\
\hline & COVID-19, 2020 & 0.78 & 0.49 & 0.55 & 0.49 & 0.44 & 0.35 & 0.19 & 0.31 & 0.31 & 0.21 & 0.24 & 0.20 & 0.13 & 0.10 & 0.34 \\
\hline & & & $-37 \%$ & $12 \%$ & $-10 \%$ & $-11 \%$ & $-20 \%$ & $-45 \%$ & $58 \%$ & $0 \%$ & $-33 \%$ & $18 \%$ & $-18 \%$ & $-36 \%$ & $-22 \%$ & $-31 \%$ \\
\hline
\end{tabular}

Table A7: Spearman correlation coefficients between air pollutants measured in selected cities

\begin{tabular}{|c|c|c|c|c|c|c|c|c|c|c|c|c|c|c|c|c|}
\hline & $\begin{array}{l}\mathrm{PM}_{2.5} \\
\text { Skopje }\end{array}$ & $\begin{array}{l}\mathrm{PM}_{2.5} \\
\text { Bitola }\end{array}$ & $\begin{array}{l}\mathrm{PM}_{2.5} \\
\text { Tetovo }\end{array}$ & $\begin{array}{l}\mathrm{PM}_{2.5} \\
\text { Kumanovo }\end{array}$ & $\begin{array}{l}\mathrm{NO}_{2} \\
\text { Skopje }\end{array}$ & $\begin{array}{l}\mathrm{NO}_{2} \\
\text { Bitola }\end{array}$ & $\begin{array}{l}\mathrm{NO}_{2} \\
\text { Tetovo }\end{array}$ & $\begin{array}{l}\mathrm{NO}_{2} \\
\text { Kumanovo }\end{array}$ & $\begin{array}{l}\mathrm{O}_{3} \\
\text { Skopje }\end{array}$ & $\begin{array}{l}\mathrm{O}_{3} \\
\text { Bitola }\end{array}$ & $\begin{array}{l}\mathrm{O}_{3} \\
\text { Tetovo }\end{array}$ & $\begin{array}{l}\mathrm{O}_{3} \\
\text { Kumanovo }\end{array}$ & $\begin{array}{l}\text { CO } \\
\text { Skopje }\end{array}$ & $\begin{array}{l}\text { CO } \\
\text { Bitola }\end{array}$ & $\begin{array}{l}\text { CO } \\
\text { Tetovo }\end{array}$ & $\begin{array}{l}\mathrm{CO} \\
\text { Kumanovo }\end{array}$ \\
\hline $\mathrm{PM}_{2.5}$ Skopje & 1 & & & & & & & & & & & & & & & \\
\hline $\mathrm{PM}_{25}$ Bitola & $0.473^{\star *}$ & 1 & & & & & & & & & & & & & & \\
\hline $\mathrm{PM}_{2.5}$ Tetovo & $0.455^{\star \star}$ & $0.753^{*}$ & 1 & & & & & & & & & & & & & \\
\hline $\mathrm{NO}_{2}$ Skopje & $0.612^{* *}$ & $0.280^{\prime \prime}$ & $0.274^{* \prime}$ & $0.253^{* *}$ & 1 & & & & & & & & & & & \\
\hline $\mathrm{NO}_{2}^{2}$ Bitola & $0.598^{* *}$ & $0.317^{*}$ & $0.182^{* *}$ & $0.132^{*}$ & $0.667^{*}$ & 1 & & & & & & & & & & \\
\hline $\mathrm{NO}_{2}$ Tetovo & $0.463^{* *}$ & $0.575^{*}$ & $0.775^{\prime \prime}$ & $0.664^{* *}$ & $0.320 "$ & $0.198^{* \prime}$ & 1 & & & & & & & & & \\
\hline $\begin{array}{l}\mathrm{NO}_{2} \\
\text { Kumanovo }\end{array}$ & $0.280^{* *}$ & $0.380^{* *}$ & $0.500^{\circ *}$ & $0.734^{\star *}$ & $0.185^{* *}$ & $0.118^{*}$ & $0.647^{* *}$ & 1 & & & & & & & & \\
\hline $\mathrm{O}_{3}$ Skopje & $-S .300^{* *}$ & $-0.158^{*}$ & $-0.136^{*}$ & -0.071 & $-0.449^{*}$ & $-0.276^{*}$ & $-0.295^{*}$ & $-0.114^{*}$ & 1 & & & & & & & \\
\hline $\mathrm{O}_{3}^{5}$ Bitola & $-0.185^{\star *}$ & $-0.274^{*}$ & $-0.124^{*}$ & $-0.134^{*}$ & -0.178 & $-0.334^{*}$ & -0.036 & -0.087 & $0.372 "$ & 1 & & & & & & \\
\hline $\mathrm{O}_{3}^{3}$ Tetovo & $-0.126^{*}$ & -0.125 & -0.041 & $-0.205^{* *}$ & 0.031 & 0.063 & $-0.146^{*}$ & $-0.184^{*}$ & $0.469^{*}$ & $0.560^{*}$ & 1 & & & & & \\
\hline $\mathrm{O}_{3}^{\circ}$ Kumanovo & $-0.146^{\star}$ & -0.019 & -0.082 & $-0.240^{* *}$ & 0.006 & 0.051 & 0.070 & $-0.119^{*}$ & $-0.221^{*}$ & 0.102 & $.0220^{* *}$ & 1 & & & & \\
\hline CO Skopje & $0.658^{* *}$ & $.345^{*}$ & $0.290^{\circ *}$ & $0.305^{\star *}$ & $0.612^{* *}$ & $0.418^{*}$ & $0.295^{*}$ & $0.202^{* *}$ & $-0.444^{* *}$ & $-0.464^{* *}$ & $-0.397^{* *}$ & $-0.205^{*}$ & 1 & & & \\
\hline CO Bitola & $0.534^{\star *}$ & $0.413^{*}$ & $0.367^{*}$ & $0.411^{* *}$ & $0.416^{* \prime}$ & $0.537^{*}$ & $0.448^{* *}$ & $0.357^{*}$ & $-0.318^{\prime \prime}$ & $-0.461^{*}$ & $-0.290^{* *}$ & -0.080 & $0.661^{*}$ & 1 & & \\
\hline CO Tetovo & $0.510^{\star *}$ & $0.309^{*}$ & $0.251^{1 *}$ & $0.405^{\star *}$ & $0.379^{*}$ & $0.357^{*}$ & $0.313^{* *}$ & $0.381^{*}$ & $-0.313^{* \prime}$ & $-0.393^{\prime \prime}$ & $-0.430^{* *}$ & $-0.175^{*}$ & $0.627^{*}$ & $0.613^{* *}$ & 1 & \\
\hline $\mathrm{CO}$ & $0.654^{* *}$ & $0.281^{*}$ & $0.213^{* *}$ & $0.304^{* *}$ & $0.556^{*}$ & $0.433^{*}$ & $0.298^{* *}$ & $0.249^{*}$ & $-0.355^{* \prime}$ & $-0.328^{* *}$ & $-0.299^{*}$ & $-0.199^{*}$ & $0.776^{* \prime}$ & $0.618^{* *}$ & $0.657^{* *}$ & 1 \\
\hline Kumanovo & & & & & & & & & & & & & & & & \\
\hline
\end{tabular}

